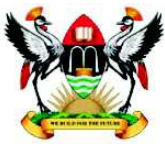

East African School of

Higher Education Studies \& Development
Makerere Journal of Higher Education

ISSN: 1816-6822; 8 (2) (2016) 107 - 113

DOI: http://dx.doi.org/10.4314/majohe.v8i2.2

(C) The Author(s) 2016

Reprints \& permission: EASHESD

http://ajol.info/majohe

\title{
Personal Attributes as Determinants of Sport Participation among Undergraduates in Selected Nigerian Universities
}

\author{
Babatunde Samson Olusola ${ }^{1}$ \\ ${ }^{1}$ Department of Human Kinetics and Health Education, University of Lagos
}

\begin{abstract}
This paper reports the findings of a study that investigated whether age, gender and marital status would be perceived as would be a significant determinant of sport participation among undergraduates in selected Nigerian universities. Data was collected using a self-constructed questionnaire from 2610 undergraduates of University of Nigeria, Nsukka and University of Benin. The findings were that students' personal attributes significantly determine their sport participation. Grounded on these findings, recommendations for the improved participation of undergraduates in sports are discussed.
\end{abstract}

Keywords: Student affairs management; Sports; Co-curricular activities.

\section{Introduction}

Effective performance in any human capacity depends largely upon the personal attributes of the individuals. Excellent performance particularly in sport is a by-product of many personal attributes such as age, gender and marital status (Babatunde, 2001).

Universities throughout the world are centres of sporting activities. Many of those who win medals at international sporting events are either students or fresh graduates. It is understandable that students in universities are mainly youths, an ideal age for developing interest in sport. Sporting activities contribute in maintaining good health among both the young and the old.

Several factors contribute to students' attitude towards sport such as age, gender and marital status. These factors form an important aspect of personal attributes which either enforce or inhibit the extent to which individuals can participate in sporting activities. 
The unique role of age in sport participation is incontestable. It is a known fact that there is a certain age noted for excellent sport performance, particularly competitive sport. Competitive sport by its very nature requires a lot of energy, power and agility. This is the more reason why competitive sports have always been identified with youths. It is expected that undergraduates would be more involved in sport as most of them are at their youthful age with varied sport potentialities and skills which if well motivated could produce excellent sport results.

Sport by nature, be it recreational or competitive, involves physical and mental coordination prowess. According to Ikulayo (1986), age has a strong influence on physical performance. The fact that universities admit a large number of youths into various courses at undergraduate level yearly makes the nation's expectation about sport development in Nigerian universities genuine most especially when considering the age of the students and sport potential as evidenced by their post-primary school sport records.

Igbanugo (1986) indicates that most undergraduates are between the age group of $22-25$. This group is noted for its ability to engage in physical exercises for prolonged period of time. This explains the physiological basis why youths are more engaged in varied physical activities like sport and do excel.

Gender, according to Fadoju (1999), refers to the social roles and expectations that are associated with being male or female which largely influence their lives. Though there are physiological differences between men and women, research shows that the two sexes are more similar than they are different.

However, the roles of men and women are undergoing significant changes both at work, play and in the family. Adeyanju (1999), in support of this view, maintains that despite the fact that many discriminatory practices exist against women involvement in sport, there are those who dare the consequences. They participate, sponsor, encourage and reward sport women. This means, if all cultural barriers hindering the participation of women in sport are removed, it is likely that women will be freed from this deprivation and discrimination. However, Babatunde (2001) is of the view that gender is a strong determinant of sport participation among undergraduates in first generation Nigerian universities. It is further discovered that male students participate in sport more than their female counterparts.

The foregoing discussion supported postulation of hypotheses that: 1) Age would be perceived as a significant determinant of sport participation among undergraduates in selected Nigerian universities; 2) Gender would be a significant determinant of sport participation among undergraduates in selected Nigerian universities; and 3) Marital status would be a significant determinant of sport participation among undergraduates in selected Nigerian universities. 
However, peculiar settings may present a unique picture. It is with this cognizance that this study undertook to verify the respective null hypotheses, taking the case of undergraduate students of the University of Ibadan, Obafemi Awolowo University, Ahmadu Bello University, University of Nigeria, Nsukka and University of Benin.

\section{$2 \quad$ Methodology}

A descriptive survey research design was utilized. Data was collected from male and female undergraduates from University of Ibadan, Obafemi Awolowo University, Ahmadu Bello University, University of Nigeria, Nsukka and University of Benin. This was done using a questionnaire based on Likert scaling design of Strongly Agree, Agree, Disagree and Strongly Disagree with the use of available sampling technique. The questionnaire was constructed by the researcher and validated by experts in the field. The reliability of the questionnaire was established using the test-retest method. This returned a correlation coefficient 0.85 , meaning that the instrument was consistent. A total of 3000 questionnaires was administered and out of these 2,610 were correctly filled and returned. The data was analysed using percentages. The hypotheses were tested at the level of confidence alpha $=.05$ using the chi-square technique.

\section{$3 \quad$ Findings and Discussion}

Hypothesis one stated that age would not be perceived as a significant determinant of sport participation among undergraduates in selected Nigerian universities. The findings on the hypothesis are summarized in Table 1.

Table 1: Distribution of respondents by level of agreement that age determines sports participation

\begin{tabular}{llllllllll}
\hline Age (Years) & SA & A & D & SD & Total & $\%$ A & $\%$ D & Total \% & $\chi^{2}$ \\
\hline $15-20$ & 300 & 380 & & 20 & 700 & 26.8 & 0.77 & 27.54 & 125.05 \\
$21-25$ & 600 & 200 & 100 & & 900 & 30.65 & 3.83 & 34.46 & \\
$26-30$ above & 500 & 300 & 120 & 90 & 1010 & 30.65 & 8.05 & 33.00 & \\
Total & 1400 & 880 & 220 & 110 & 2610 & 87.35 & 12.65 & 100 & \\
\hline
\end{tabular}

The findings clearly show that age is an important variable which determines the participatory pattern of students in sport. This is in line with Anyanwu's (1999) assertion that age is a major factor in sport participation because 
advancement in age decreases one's ability to endure environmental stress, working capacity, physical fitness, strength, endurance and oxygen up-take. In related study, Babatunde (2001) also finds that there is a strong connection between the age of students and their desire to take part in school sport as it is evident that most athletes in Nigerian universities are often between $21-25$ years. In justifying the role of age in recreational activities, Ahmed (2016) found that age is a critical factor in the participatory pattern of students in sports at tertiary institutions in Nigeria. It was observed that students between 18-30years were observed to participate more in school sports, either competitive or recreation.

Hypothesis 2 stated that gender would not be a significant determinant of sport participation among undergraduates in selected Nigerian universities. The findings are summarized in Table 2.

Table 2: Distribution of respondents by level of agreement that gender determines sports participation

\begin{tabular}{lllllll}
\hline Respondents & SA & A & D & SD & Total & $X^{2}$ \\
\hline Male & 1,000 & 200 & -- & 410 & 1600 & 225.45 \\
Female & 800 & 100 & 100 & -- & 1000 & \\
Total & 1,800 & 300 & 100 & 410 & 2,600 & \\
\hline
\end{tabular}

The above table provides empirical information concerning issue of gender and sport participation in selected Nigerian universities. Going through the table, it is observed that the calculated $\mathrm{X}^{2}$ value of 225.45 at $\mathrm{df} 3$ and 0.05 level of significance is greater than the $\mathrm{X}^{2}$ table value of 7.815 . This had made the researchers to reject the hypothesis that gender would not be a significant determinant of sport participation among undergraduates in selected Nigerian universities.

The findings which show that gender significantly determines sport participation among undergraduates in selected Nigerian universities corroborates the findings of Honeybourne, Hill and Moors (1996), Akinsanmi (1997), Orunanoka (1997), and Babatunde (2001) that gender has a significant bearing with sport participation as against Adeyanju's (1999) postulation that despite the fact that many discriminatory practices exist against women involvement in sport, there are those who dare the consequences. Babatunde. (2012) reported that gender significantly accounts for disparity in sports participation among students in Nigerian Universities.

Hypothesis 3 stated that marital status would not be a significant determinant of sport participation among undergraduates in selected Nigerian universities. The findings on the hypothesis are shown in Table 3. 
Table 3: Distribution of respondents by level of agreement that marital status determines sports participation

\begin{tabular}{llllll}
\hline Categories & Count & $\%$ & $\mathrm{X}^{2}$ & Agreement/ Disagreement & Remark \\
\hline SA & 305 & 11.7 & & & \\
A & 1519 & 58.2 & 416.1 & 84.2 & 5 \\
D & 678 & 26.0 & & & \\
SD & 107 & 4.1 & & 15.8 & \\
Total & 2610 & 100 & & 100 & \\
\hline
\end{tabular}

From the table above, the chi-square $X^{2}$ is 416.6 as against $X^{2}$ table value of $7.815,3 \mathrm{df}$ at 0.05 level of significance allows the researchers to reject the hypothesis that marital status would not be a significant determinant of sport participation among undergraduates in selected Nigerian universities.

Babatunde (2001) finds that marital status significantly dictates the zest of the students in participating in sport. Most of the students, if not all, who get involved in the school sport, particularly competitive sport, are predominantly unmarried.

\section{Conclusions and Recommendations}

Based on the findings of this study, the following conclusions and recommendations are made:

1. Age is identified as a significant variable determining students' sport involvement in selected Nigerian universities.

2. Gender is found to significantly determine sport participation among undergraduates in selected Nigerian universities as more male students than female students get involved in sport at tertiary institutions.

3. Marital status is also perceived by the students as a significant determinant of sport participation among undergraduates in selected universities in Nigeria.

4. There is need for empirical research on marital status and sport participation in order to establish the reasons why married individuals shun sport. This will help university sport administrators in their efforts to address the constraints facing this group of students.

5. More research is also imperative to educate athletes on how to manage themselves so as to prevent rapid ageing resulting from careless lifestyle and its attendant effects. This will keep them long in active sporting activities, without undue "wear out" that may lead to poor performance.

6. Age-long taboos forbidding female students from participating in sport should be de-emphasized to encourage better female participation in sport by 
making them realize that sport participation by women has no adverse implication on their femininity and body chemistry.

7. For a successful development of sport among undergraduates, the efforts of the university authorities should be directed at strategies capable of motivating the students towards sport participation such as provision of accommodation for students on campus, provision of necessary equipment, facilities and maintaining these properly. Availability of these will provide the needed incentive that will motivate students to participate in sporting activities.

\section{References}

Adeyanju, F. B. (1999). Women and sports in Nigeria. Problems and perspectives in the next millennium. In Aderinokun, E., Adeniji, N. \& Ajibode (eds.) Sports development in Nigeria in the next millennium. Ibadan: Codat Publications: Page 22-34.

Ahmed, A. A. (2016). Perceived factors influencing recreational participation of female students of Adekumle Ajasin University, Akungba Akoko, Ondo State, Nigeria, Journal of University of University Port Harcourt of Nigeria Association for Physical, Health, Education, Recreation, Sports and Dance, 3,30-37

Akinsanmi, T. (1992). Women participation in sports: A case study of Adeyemi College of Education. In Amusa, L. O. (ed.) Ondo Sports Science and Medicine.

Akinsanmi, T. (1997). Barriers to female sports management and participation: The experience in selected Nigerian colleges of education. The female and physical activity. Proceeding of the $11^{\text {th }}$ Annual Conference of Nigeria Association of Sports Science and Medicine (NASSM).

Anyanwu, S. U. (1999). Youth in sports: The cornerstone of sports development. In Aderinokun, E., Adeniji, N. \& Ajibade, F. T. (eds.) Sports development in Nigeria in the next millennium, pp. 66 - 71. Ibadan: Codat Publications.

Babatunde, S. O. (2001). Socio-cultural determinants of sports participation among undergraduates in first generation Nigerian universities. Doctoral thesis.

Babatunde, S. O. (2012). Recreation as complementary capacity building strategy among Oyo state civil servants. African Journal of Sports Science, 6, 109-119. 
Fadoju, A. O. (1999). Introduction to sociology of sports. In Moronkola, O. A. (ed.) Essentials of human kinetics and health education. Ibadan: Codat Publications.

Hall, A. (1990). How should one theorize gender in the contest of sport? In Mesner, M. \& Sabo, D. (eds.) Sport, men and gender order: Campaign in human kinetics.

Honeybourne, J., Hall, M. \& Moors, H. (1996). Advanced physical education and sports. United Kingdom: Stanley Thornes (Publishers).

Igbanugo, V. C. (1986). Effective organization of sports: Relationship to performance. Organization of sports in Nigerian universities. Proceedings of Guinness NUGA 1986 Sports Clinic.

Ikulayo, P. B. (1986). Towards achieving the nations sports performances expectations by Nigeria universities' students. Organizations of sports in Nigerian Universities. Proceedings of Guinness NUGA 1986 Sports Clinic. 